\title{
TELAAH KRITIS TERHADAP INKONSISTENSI KONSEP HUBUNGAN KERJA DALAM UNDANG-UNDANG NOMOR 13 TAHUN 2003 TENTANG KETENAGAKERJAAN
}

\author{
Ujang Charda S. \\ Dosen Tetap Fakultas Hukum Universitas Subang \\ E-mail: ujangch@gmail.com
}

\begin{abstract}
Act No. 13 of 2003 provides a formula, that the employment relationship occurs because of an agreement the work done by workers and employers that contains elements of employment, orders, and wages. If the work is not based on the employment agreement and is not done by workers with employers, and not mampunyai these three elements, meaning not the employment relationship. Meanwhile, the formulation of the employment agreement severely restricts the legal subject in the employment relationship, the employee who works on businessmen and entrepreneurs who run the company, either hers or not. The problem is if there are people who employ other people, but not currently in running the company, then the other person is not the workers covered by Act No. 13 of 2003. It is very clear formulation of Act No. 13 of 2003 do not understand the legal concepts of the subject law labor relations, should not the employer who become the subject of law but employers.
\end{abstract}

Keywords: Inconsistency; Employment and Labour.

\begin{abstract}
Abstrak
Undang-Undang Nomor 13 Tahun 2003 memberikan rumusan, bahwa hubungan kerja terjadi karena adanya perjanjian kerja yang dilakukan oleh pekerja dan pengusaha yang memuat unsur pekerjaan, perintah, dan upah. Apabila yang bekerja tidak berdasarkan perjanjian kerja serta tidak dilakukan oleh pekerja dengan pengusaha, dan tidak mampunyai ketiga unsur tersebut, berarti bukan hubungan kerja. Sementara itu, rumusan perjanjian kerja sangat membatasi subjek hukum dalam hubungan kerja, yaitu pekerja yang bekerja pada pengusaha dan pengusaha yang menjalankan perusahaan, baik miliknya atau bukan. Masalahnya apabila ada orang yang mempekerjakan orang lain, tetapi tidak sedang dalam menjalankan perusahaan, maka orang lain itu bukan pekerja yang dilindungi oleh Undang-Undang Nomor 13 Tahun 2003. Tampak sekali perumusan Undang-Undang Nomor 13 Tahun 2003 kurang memahami konsep hukum mengenai subjek hukum hubungan kerja, seharusnya bukan pengusaha yang menjadi subjek hukum tetapi pemberi kerja.
\end{abstract}

Kata Kunci: Inkonsistensi, Hubungan Kerja, Ketenagakerjaan. 


\section{A. PENDAHULUAN}

Pembangunan ketenagakerjaan mempunyai banyak dimensi yang tidak hanya berhubungan dengan kepentingan tenaga kerja yang akan, sedang, dan sesudah masa kerja, ${ }^{1}$ tetapi bagaimana caranya agar semua orang mendapatkan pekerjaan dan penghidupan yanglayakbagi kemanusiaan tanpa adanya diskriminatif dalam pelaksanaan hubungan kerja. ${ }^{2} \mathrm{Hak}$ untuk bekerja (the right to work) ${ }^{3}$ dan hakhak dalam pekerjaan (the rights in work) bukan hanya sebagai hak sosial ekonomi, melainkan juga merupakan hak-hak manusia yang fundamental (fundamental human rights). ${ }^{4}$

Hal tersebut berimplikasi pada tanggungjawabnegara untukmemfasilitasi dan melindungi warga negaranya agar dapat memperoleh penghasilan dengan standar penghidupan yang layak, sehingga mampu memenuhi kebutuhan hidupnya secara wajar atas dasar harkat dan martabat kemanusiaan. ${ }^{5}$ Oleh karena itu, dalam memberikan perlindungan hukum terhadap tenaga kerja perlu perencanaan matang untuk mewujudkan tanggung jawab negara tersebut. ${ }^{6}$ Dalam praktik kebijakan legislasi selama ini, dijumpai fenomena kebijakan formulasi hukum ketenagakerjaan yang mengandung permasalahan dan/atau kelemahan berkaitan dengan konsep hubungan kerja yang inkonsisten antara satu pasal dengan pasal yang lainnya. Di dalam UndangUndang Nomor 13 Tahun 2003 tentang Ketenagakerjaan, secara substansial kriteria bekerja di dalam hubungan kerja terjadi karena adanya perjanjian kerja yang dilakukan oleh pekerja dan pengusaha yang memuat unsur pekerjaan, perintah, dan upah. Apabila yang bekerja tidak ada hubungan kerja yang lahir dari perjanjian serta tidak dilakukan oleh pekerja dengan pengusaha, serta tidak mampunyai ketiga unsur tersebut, artinya kerja sendiri, berarti bekerja di luar hubungan kerja.

Hal tersebut dapat dilihat dalam rumusan Pasal 1 angka 15 jo. Pasal 50 - Pasal 66 Undang-Undang Nomor 13 Tahun 2003 subjek hukum dari hubungan kerja adalah pengusaha dengan pekerja/buruh, sehingga batasan subjek hukum berdasarkan ketentuan di atas sangat sempit. Batasan subjek hukum akan berbeda apabila didasarkan pada ketentuan Pasal 1 angka 14 UndangUndang Nomor 13 Tahun 2003, yaitu

$1 \quad$ Pasal 1 angka 1 Undang-Undang Nomor 13 Tahun 2003 tentang Ketenagakerjaan.

2 Ujang Charda S., Perlindungan Hukum Terhadap Anak dari Bentuk-bentuk Pekerjaan Terburuk, Fakultas Hukum Universitas Subang, Subang, 2015, hlm. 1.

3 Amidhan, "Tinjauan Tingginya Angka Pengangguran dari Perspektif Hak Asasi Manusia", Semiloka Memetakan Akar Masalah dan Solusi Tingginya Angka Pengangguran di Indonesia, Purwakarta, 18-19 Juli 2005, hlm. 3.

$4 \quad$ Ujang Charda S., "Tanggung Jawab Negara Indonesia dalam Perlindungan Hukum Terhadap Tenaga Kerja Anak", Jurnal Wawasan Hukum, Vol. 30 No. 1, STHB, Bandung, Maret 2014, hlm. 1.

5 Maslow mengemukakan bahwa kebutuhan hidup itu pada dasarnya mencakup : food, shelter, clothing; safety of self and property; self esteem; self actualization dan love yang kesemuanya merupakan kebutuhan kodrati manusia sebagai prasyarat untuk kondisi sehat mental. Lihat Purnadi Purbacaraka \& Soerjono Soekanto, Perihal Kaidah Hukum, Citra Aditya Bakti, Bandung, 1993, hlm. 5. Lihat juga Malayu S.P. Hasibuan, Manajemen : Dasar, Pengertian, dan Masalah, Bumi Aksara, Jakarta, 2003, hlm. 226-227.

$6 \quad$ Adrian Sutedi, Hukum Perburuhan, Sinar Grafika, Jakarta, 2009, hlm. 1. 
perjanjian kerja adalah perjanjian antara pekerja/buruh dengan pengusaha atau pemberi kerja yang memuat syaratsyarat kerja, hak, dan kewajiban para pihak. Apabila dilakukan perbandingan antara ketentuan Pasal 1 angka 14 dengan ketentuan Pasal 1 angka 15 jo. Pasal 50 Pasal 66 Undang-Undang Nomor 13 Tahun 2003, maka terdapat perbedaan akibat hukumnya. Unsur-unsur dari ketentuan Pasal 1 angka 14 Undang-Undang Nomor 13 Tahun 2003 adalah subjek hukum perjanjian kerja terdiri dari pekerja/buruh dengan pengusaha atau pemberi kerja, sedangkan yang menjadi objek perjanjian kerjanya adalah syarat-syarat kerja, hak, dan kewajiban para pihak. Unsur-unsur tersebut berbeda dengan ketentuan Pasal 1 angka 15 jo. Pasal 50 - Pasal 66 Undang-Undang Nomor 13 Tahun 2003 dengan subjek hukum perjanjian kerjanya adalah pengusaha dengan pekerja/buruh, sedangkan yang menjadi objek perjanjian kerjanya adalah pekerjaan, upah, dan perintah.? $^{7}$

Berdasarkan rumusan tersebut menimbulkan pemisahan pengaturan antara yang bekerja di dalam dan di luar hubungan kerja dalam konteks hukum ketenagakerjaan tidak sesuai dengan asas perlindungan hukum ketenagakerjaan. ${ }^{8} \mathrm{Di}$ samping itu juga tidak sesuai dengan tujuan utama hukum ketenagakerjaan, ${ }^{9}$ hakikat hukum ketenagakerjaan, ${ }^{10}$ sifat hukum ketenagakerjaan, ${ }^{11}$ serta ruang lingkup hukum ketenagakerjaan yang secara gramatikal dirumuskan sebagai segala hal yang berhubungan dengan tenaga kerja pada waktu sebelum, selama, dan

$7 \quad$ Ujang Charda S., "Perlindungan Hukum Terhadap Tenaga Kerja Anak yang Bekerja di Luar Hubungan Kerja pada Bentuk-bentuk Pekerjaan Terburuk Dihubungkan dengan Prinsip Tanggung Jawab Negara Hukum", Disertasi, Program Pascasarjana UNISBA, Bandung, 2015, hlm. 356-357.

8 Penjelasan Pasal 3 Undang-Undang Nomor 13 Tahun 2003 tentang Ketenagakerjaan mengemukakan, bahwa pembangunan ketenagakerjaan diselenggarakan atas asas keterpaduan dengan melalui koordinasi fungsional lintas sektoral pusat dan daerah. Asas pembangunan ketenagakerjaan pada dasarnya sesuai dengan asas pembangunan nasional, khususnya asas demokrasi Pancasila serta asas adil dan merata. Pembangunan ketenagakerjaan mempunyai banyak dimensi dan keterkaitan dengan berbagai pihak yaitu antara pemerintah, pengusaha dan pekerja/buruh. Oleh sebab itu, pembangunan ketenagakerjaan dilaksanakan secara terpadu dalam bentuk kerja sama yang saling mendukung.

9 Pasal 4 Undang-Undang Nomor 13 Tahun 2003 mengemukakan, bahwa tujuan pembangunan ketenagakerjaan adalah memberdayakan dan mendayagunakan tenaga kerja secara optimal dan manusiawi, mewujudkan pemerataan kesempatan kerja dan penyediaan tenaga kerja yang sesuai dengan kebutuhan pembangunan nasional dan daerah, memberikan perlindungan kepada tenaga kerja dalam mewujudkan kesejahteraan, dan meningkatkan kesejahteraan tenaga kerja dan keluarganya.

10 Maksud dari hakikat hukum ialah membawa aturan yang adil dalam masyarakat (rapport du droit, inbreng van recht) atau semua arti lain yang menunjuk ke arah ini sebagai arti dasar segala hukum. Lihat Theo Huijbers, Filsafat Hukum, Kanisius, Yogyakarta, 1995, hlm. 77.

11 Sifat dari hukum ketenagakerjaan bukan hanya bersifat privat mengatur kepentingan orang perorang, dalam hal ini adalah antara tenaga kerja dan pengusaha, yaitu di mana mereka mengadakan suatu perjanjian yang disebut dengan perjanjian kerja, tetapi dalam perkembangannya mengalami pergeseran ke arah yang memiliki sifat-sifat publik, karena menyangkut pengaturan mengenai kebijakan pemerintah dalam bidang ketenagakerjaan. Hukum ketenagakerjaan sebagai bagian dari hukum publik melibatkan peran negara yang cukup dominan, sehingga diharapkan negara dapat tanggap dan menjadi fasilitator kedua kepentingan kelompok, yaitu antara pekerja dan pengusaha. Pada sisi lain ada yang menilai, bahwa hukum ketenagakerjaan ini menjadi alat untuk melegitimasi tindakan pemerintah. Lihat Ujang Charda S., "Reorientasi Reformasi Model Hukum Ketenagakerjaan dalam Kebijakan Pemerintah", Jurnal Ilmu Hukum Syiar Hukum, Vol. XIV No. 1, Fakultas Hukum UNISBA, Bandung, Maret 2012, hlm. 15. 
sesudah masa kerja. ${ }^{12}$ Dengan demikian, pembahasan Hukum Ketenagakerjaan bukan hanya menyangkut di dalam hubungan kerja saja, melainkan juga orang yang bekerja di luar hubungan kerja. Hal ini beda dengan pembahasan dengan Hukum Perburuhan yang hanya menyangkut orang yang bekerja pada orang lain dalam suatu hubungan kerja dengan menerima upah atau imbalan dalam bentuk lain. ${ }^{13}$

\section{B. PEMBAHASAN}

\section{Konsep Hubungan Kerja}

Hubungan kerja atau hubungan perburuhan atau hubungan industrialyang merupakan istilah dari labour relations, labour management relations, industrial relations ${ }^{14}$ adalah suatu hubungan antara seorang pekerja/buruh dengan seorang pengusaha yang menunjukkan kedudukan kedua belah pihak yang pada dasarnya menggambarkan hak-hak dan kewajibankewajiban pekerja/buruh terhadap pengusaha serta hak-hak dan kewajibankewajiban pengusaha terhadap pekerja/ buruh. ${ }^{15}$ Adanyahubungan kerja terjadibila ada pekerja/buruh dan pengusaha sebagai subjek hukumnya, sedangkan hubungan antara seorang yang bukan pekerja/buruh dengan seorang yang bukan pengusaha, namanya bukan hubungan kerja. ${ }^{16}$

Menurut Iman Soepomo, bahwa pada dasarnya hubungan kerja adalah hubungan antara buruh dan majikan terjadi setelah diadakannya perjanjian oleh buruh dengan majikan, di mana buruh menyatakan kesanggupannya untuk bekerja pada majikan dengan menerima upah dan di mana majikan menyatakan kesanggupannya untuk mempekerjakan buruh dengan membayar upah. ${ }^{17}$ Adanya hubungan kerja terjadi bila ada pekerja/ buruh dan pengusaha sebagai subjek hukumnya, sedangkan hubungan antara seorang yang bukan pekerja/buruh dengan seorang yang bukan pengusaha, namanya bukan hubungan kerja. ${ }^{18}$

Di dalam Pasal 1 angka 15 UndangUndang Nomor 13 Tahun 2003, dirumuskan secara formal pengertian hubungan kerja sebagai hubungan antara pengusaha ${ }^{19}$ dengan pekerja/buruh ${ }^{20}$ berdasarkan perjanjian kerja yang memuat unsur pekerjaan, upah, dan perintah. Rumusan

12 Ujang Charda S., Mengenal Hukum Ketenagakerjaan Indonesia (Sejarah, Teori \& Praktiknya di Indonesia, FH UNSUB, Subang, 2014, hlm. 4.

13 Koko Kosidin, "Aspek-aspek Hukum dalam Pemutusan Hubungan Kerja di Lingkungan Perusahaan Perseroan (Persero)", Disertasi, Program Pascasarjana Universitas Padjadjaran, Bandung, 1996, hlm. 305-306.

14 Ujang Charda S., Transformasi Politik Hukum Ketenagakerjaan Indonesia (Sebuah Orientasi Reformasi Kebijakan Pemerintah Indonesia dalam Pembangunan Ketenagakerjaan), Fakultas Hukum Universitas Subang, Subang, 2016, hlm. 129.

15 Menurut Iman Soepomo, bahwa pada dasarnya hubungan kerja adalah hubungan antara buruh dan majikan terjadi setelah diadakannya perjanjian oleh buruh dengan majikan, di mana buruh menyatakan kesanggupannya untuk bekerja pada majikan dengan menerima upah dan di mana majikan menyatakan kesanggupannya untuk mempekerjakan buruh dengan membayar upah. Lihat Iman Soepomo, Pengantar Hukum Perburuhan, Djambatan, Jakarta, 1999, hlm. 70.

16 Abdul Rachmad Budiono, Hukum Perburuhan, Indeks, Jakarta, 2009, hlm. 22.

17 Ibid.

18 Ibid

19 Lihat Pasal 1 angka 5 Undang-Undang Nomor 13 Tahun 2003 tentang Ketenagakerjaan.

20 Pasal 1 angka 3 Undang-Undang Nomor 13 Tahun 2003 tentang Ketenagakerjaan. 
Pasal 1 angka 15 Undang-Undang Nomor 13 Tahun 2003 mengandung hal-hal yang melekat pada hubungan sebagai berikut:

a. Subjek hukum

Subjek hukum pendukung hubungan kerja adalah pengusaha dan pekerja/buruh, sehingga tidak ada hubungan kerja apabila subjek hukum pendukungnya bukan pekerja/buruh dan pengusaha. Di dalam hubungan kerja kedudukan pengusaha adalah sebagai pemberi kerja, sehingga berhak dan sekaligus berkewajiban untuk memberikan perintah-perintah yang berkaitan dengan pekerjaannya. Kedudukan pihak pekerja/buruh adalah sebagai pihak yang menerima perintah untuk melaksanakan pekerjaan. Hubungan antara pengusaha dan pekerja/buruh adalah hubungan yang dilakukan antara atasan dan bawahan, sehingga bersifat subordinat (hubungan yang bersifat vertikal).

b. Adanya perjanjian kerja

Perjanjian kerja bertujuan untuk melindungi para pihak apabila timbul sengketa, maka perjanjian kerja tertulis merupakan alat bukti yang sah di pengadilan, sehingga perjanjian kerja harus merumuskan kehendak kedua belah pihak secara jelas dan tegas. ${ }^{21}$ Pentingnya peran perjanjian kerja dalam hubungan kerja mendorong perlunya suatu kesadaran untuk menempatkan pekerja/buruh dan pemberi kerja tunduk pada perjanjian kerja. ${ }^{22}$

Untuk menandai hubungan kerja, D. Koeshartono dan M.F. Shellyana Junaedi menjelaskan sebagai berikut: ${ }^{23}$ “... terdapat tiga unsur yang menentukan adanya hubungan kerja, yaitu adanya pekerjaan yang harus dilakukan, perintah, dan upah. Tanpa adanya salah satu dari ketiga unsur tersebut, maka tidak ada hubungan kerja".

Penegasan yang sama tentang syarat hubungan kerja dikemukakan oleh Soedarjadi dengan mengemukakan, bahwa apabila dalam melaksanakan pekerjaan tidak terdapat unsur pekerjaan, upah, dan perintah, maka tidak terdapat hubungan kerja dan bila timbul perselisihan atau beda pendapat sulit diselesaikan dengan undang-undang ketenagakerjaan. ${ }^{24}$

Dalam kaitannya dengan bentuk perjanjian kerja, D. Koeshartono dan M.F. Shellyana Junaedi mengatakan sebagai berikut: ${ }^{25}$

"Bentuk perjanjian kerja hendaknya bersifat bebas, artinya perjanjian tersebut dapat dibuat secara lisan maupun tertulis. Perjanjian kerja yang dibuat secara tertulis lebih menjamin adanya kepastian hukum".

Juanda Pangaribuan, Kedudukan Dosen dalam Hukum Ketenagakerjaan, BIS, Jakarta, 2011, hlm. 23. Ibid.

23 D. Koeshartono dan M.F. Shellyana Junaedi, Hubungan Industrial Kajian Konsep dan Permasalahannya, Universitas Atmajaya, Yogyakarta, 2005, hlm. 59.

24 Soedarjadi, Hukum Ketenagakerjaan di Indonesia, Pustaka Yustisia, Yogyakarta, 2008, hlm. 22-23.

25 D. Koeshartono dan M.F. Shellyana Junaedi, Op. Cit., hlm. 60. 
Menurut Iman Soepomo, perjanjian kerja perlu untuk melindungi buruh $^{26}$ yang dalam pemahaman luas gagasan itu menekankan, bahwa setiap hubungan kerja harus dengan perjanjian kerja secara tertulis agar mampu melindungi pihak yang berkedudukan lebih lemah. ${ }^{27}$ Sementara itu, dilihat dari segi fungsinya Iman Soepomo mengatakan, bahwa perjanjian kerja secara tertulis dapat berfungsi sebagai alat bukti yang sah di pengadilan. Lebih lanjut Iman Soepomo berpendapat, sebagai berikut: $^{28}$

"Dengan tiada surat, juga tiada perjanjian ... perjanjian kerja ... hanya dapat dibuktikan dengan surat tersebut. Artinya jika tiada surat perjanjian, tiada pula perjanjian. Surat itu adalah unsur pembentukan".

Hubungan kerja terjadi karena adanya perjanjian kerja antara pengusaha dengan pekerja/ buruh, $^{29}$ sehingga merupakan syarat administrasi dalam memulai hubungan kerja yang minimal dilakukan oleh dua subjek hukum mengenai suatu pekerjaan ${ }^{30}$ dan perjanjian kerja merupakan bukti dari suatu ikatan hukum yang mengatur serta melahirkan hak dan kewajiban. ${ }^{31}$ Hal yang dapat disimpulkan, bahwa hubungan kerja hanya lahir karena perjanjian kerja yang melahirkan perikatan dan perikatan yang lahir karena perjanjian kerja ini yang disebut hubungan kerja. ${ }^{32}$

Digunakannya perkataan hubungan kerja untuk menunjukkan hubungan hukum antara pengusaha dan pekerja/buruh mengenai kerja ${ }^{33}$ mengandung arti, bahwa pihak pekerja/buruh dalam melakukan pekerjaan berada di bawah pimpinan/ perintah pengusaha ${ }^{34}$ atau adanya suatu hubungan diperatas, yaitu satu pihak berhak memberikan perintahperintah yang harus ditaati oleh yang lain. ${ }^{35}$

Pemaknaan di atas akan lebih jelas, apabila dikaitkan dengan pengertian perjanjian kerja dan pengertian pemberi kerja. Perjanjian kerja adalah sebagai perjanjian antara pekerja/buruh dengan pengusaha atau pemberi kerja yang memuat syarat-syarat kerja, hak, dan kewajiban para pihak. ${ }^{36}$ Sementara itu, pemberi kerja adalah orang perseorangan, pengusaha, badan hukum, atau badan-

\footnotetext{
26 Juanda Pangaribuan, Op. Cit., hlm. 66.

27 Ibid., hlm. 67.

28 Ibid.

29 Pasal 50 Undang-Undang Nomor 13 Tahun 2003 tentang Ketenagakerjaan.

30 Asri Wijayanti, Menggugat Konsep Hubungan Kerja, Lubuk Agung, Bandung, 2011, hlm. 55.

31 Juanda Pangaribuan, Op. Cit., hlm. 24.

32 Abdul Rachmad Budiono, Hukum .... Loc. Cit., hlm. 22.

33 Abdul Rachmad Budiono, Hukum Perburuhan di Indonesia, RajaGrafindo Persada, Jakarta, 1999, hlm. 25.

34 Iman Soepomo, Hukum Perburuhan Bidang Hubungan Kerja, Djambatan, Jakarta, 1983, hlm. 1.

35 Subekti, Aneka Perjanjian, Alumni, Bandung, 1985, hlm. 58.

36 Pasal 1 angka 14 Undang-Undang Nomor 13 Tahun 2003 tentang Ketenagakerjaan.
} 
badan lainnya yang mempekerjakan tenaga kerja dengan membayar upah atau imbalan dalam bentuk lain. ${ }^{37}$

Apabila batasan hubungan kerja, perjanjian kerja, dan pemberi kerja dikaitkan, selain akan melahirkan hubungan kerja dan perjanjian dapat melahirkan hubungan hukum lain. Hal ini didasarkan pada kenyataan, bahwa perjanjian kerja dapat dibuat oleh pekerja/buruh dan pengusaha atau pekerja/buruh dan pemberi kerja. Hubungan hukum antara pekerja/ buruh dengan pengusaha merupakan hubungan kerja, ${ }^{38}$ sedangkan hubungan antara pekerja/buruh dengan pemberi kerja tetapi bukan sebagai pengusaha merupakan hubungan lain (bukan hubungan kerja).

Pemberi kerja merupakan subjek hukum yang pengertiannya lebih luas daripada pengusaha, hal inimerupakan pembenar bahwa perjanjian kerja dapat dibuat oleh subjek hukum lain selain pengusaha. Dengan demikian, hal yang dapat disimpulkan, bahwa perjanjian kerja antara pekerja/buruh dengan pemberi kerja yang bukan pengusaha melahirkan hubungan hukum bukan hubungan kerja. ${ }^{39}$

c. Adanya unsur pekerjaan, upah, dan perintah

Hubungan hukum yang dilekati dengan unsur pekerjaan, upah, dan perintah yang mempunyai sifat kumulatif merupakan hubungan kerja. Artinya, ketiadaan salah satu unsur menyebabkan tidak ada hubungan kerja, karena ketiga unsur ini yang membedakan antara hubungan kerja di satu sisi dengan hubungan hukum di lain sisi, sehingga hal ini memberikan kekhasan pada hubungan kerja jika dibandingkan dengan hubungan hukum lainnya yang di dalamnya juga ada unsur pekerjaan, misalnya hubungan antara seorang dokter dengan pasien, advokat dengan klien, notaris dengan klien, akuntan dengan klien (pengguna jasa akuntan) bukan merupakan hubungan kerja, sebab dokter, advokat, notaris, dan akuntan tidak berada di bawah perintah pasien atau klien tersebut. ${ }^{40}$

Selanjutnya menurut Iman Soepomo, bahwa hubungan kerja pada dasarnya meliputi soal-soal yang berkaitan dengan: ${ }^{41}$

a. Pembuatan perjanjian kerja, karena merupakan titik tolak adanya suatu perjanjian kerja.

b. Kewajiban pekerja/buruh melakukan pekerjaan pada atau di bawah pimpinan pengusaha, sekaligus merupakan hak pengusaha atas pekerjaan pekerja/buruh.

c. Kewajiban pengusaha membayar upah kepada pekerja/buruh sekaligus merupakan hak pekerja/buruh atas upah.

\footnotetext{
Pasal 1 angka 4 Undang-Undang Nomor 13 Tahun 2003 tentang Ketenagakerjaan. Pasal 1 angka 15 Undang-Undang Nomor 13 Tahun 2003 tentang Ketenagakerjaan. Abdul Rachmad Budiono, Hukum .... Loc. Cit., hlm. 22.

Ibid., hlm. 23.

Iman Soepomo dalam Payaman J. Simanjuntak, Manajemen Hubungan Industrial, FEUI, Jakarta, 2011, hlm. 231.
} 
d. Berakhirnya hubungan kerja.

e. Caranya perselisihan antara pihakpihak yang bersangkutan diselesaikan dengan sebaik-baiknya.

Merujuk pada pendapat Iman Soepomo, bahwa komponen hubungan kerja di atas, menegaskan bahwa hubungan kerja selalu ditandai dengan perjanjian kerja yang dalam konteks hubungan kerja ini, perjanjian kerja itu mengatur hak dan kewajiban para pihak. ${ }^{42}$ Menyadari daya mengikat perjanjian kerja yang kuat dan memaksa, bahwa isi perjanjian kerja tidak boleh bertentangan dengan undang-undang, ketertiban umum, dan tata susila masyarakat ${ }^{43}$ yang tidak dapat dipisahkan dari sistem kebebasan berkontrak sebagaimana diatur dalam Pasal 1338 KUH Perdata. Syarat itu berfungsi sebagai pembatas, sehingga pihak yang membuat perjanjian tidak terjerumus dengan kebebasannya. Oleh karena itu, ketiga syarat tersebut merupakan syarat substansi yang bertujuan melindungi salah satu pihak yang apabila bertentangan dengan tiga syarat tersebut, maka perjanjian itu batal demi hukum. ${ }^{4}$

Syarat yang mengharuskan perjanjian kerja tidak bertentangan dengan undangundang, ketertiban umum, dan tata susila berpararel dengan Pasal 1320 KUH Perdata yang mengatur empat syarat sahnya suatu perjanjian, yaitu: a. Sepakat mereka yang mengikatkan dirinya.

b. Kecakapan untuk membuat suatu perikatan.

c. Suatu hal tertentu.

d. Suatu sebab yang halal.

Pararel dengan syarat perjanjian di atas, secara khusus menurut Pasal 52 ayat (1) Undang-Undang Nomor 13 Tahun 2003, bahwa perjanjian kerja dibuat atas dasar:

a. Kesepakatan kedua belah pihak.

b. Kemampuan atau kecakapan melakukan perbuatan hukum.

c. Adanya pekerjaan yang diperjanjikan.

d. Pekerjaan yang diperjanjikan tidak bertentangan dengan ketertiban umum, kesusilaan, dan peraturan perundang-undangan yang berlaku.

Di dalam kepustakaan, dua syarat pertama disebut syarat subjektif, sedangkan dua syarat terakhir disebut syarat objektif. Tidak terpenuhinya syarat subjektif berakibat dapat dibatalkannya perjanjian (nietigheid), sedangkan tidak terpenuhinya syarat objektif berakibat batal demi hukumnya perjanjian itu (nietigbaarheid). ${ }^{45}$ Kebatalan nietigheid atau batal demi hukum tidak perlu perbuatan hukum tertentu yang oleh N.E. Algra disebut dengan kebatalan mutlak, ${ }^{46}$ sedangkan kebatalan suatu nietigbaarheid atau dapat dibatalkan perlu perbuatan hukum tertentu. ${ }^{47}$

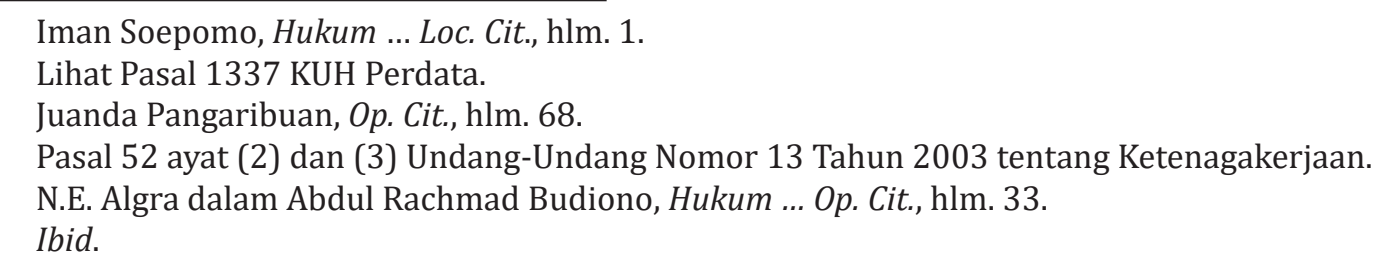


Dibandingkan dengan perjanjian hukum lainnya, perjanjian kerja disebut sebagai perjanjian khusus. Artinya terdapat ketentuan perundang-undangan yang membatasi kebebasan pihak-pihak untuk mengadakan perjanjian, karena perjanjian kerja harus memperhatikan batas-batas tertentu dari hukum positif atau dengan kata lain, substansi perjanjian kerja tidak boleh lebih rendah atau bertentangan dengan ketentuan hukum positif, misalnya dalam hal upah tidak boleh memperjanjikan upah lebih rendah dari upah minimum.

\section{Inkonsistensi Konsep Hubungan Kerja dalam Undang-Undang Nomor 13 Tahun 2003 tentang Ketenagakerjaan}

Pola hubungan kerja erat kaitannya dengan hak tenaga kerja yang selalu berkaitan dengan adanya perlindungan hukum bagi pihak yang mempunyai kedudukan lebih lemah di dalam hubungan kerja, seperti anak. Di dalam hubungan kerja yang merupakan salah satu jenis hubungan hukum terdapat kondisi yang tidak seimbang apabila ditinjau dari sudut sosial ekonomi, karena kedudukan tenaga kerja lebih rendah daripada kedudukan pemberi kerja.

Pada dasarnya subjek hukum dalam suatu hubungan kerja adalah kewajiban dan hak tenaga kerja, yaitu melakukan pekerjaan yang dijanjikan dan menerima upah, sedangkan kewajiban dan hak majikan/pengusaha, yaitu membayar upah dan menuntut tenaga kerja bekerja sesuai dengan pekerjaan yang diperjanjikan. ${ }^{48}$ Dengan demikian, sejatinya dalam rezim hukum perdata yang harus dilindungi secara hukum adalah keempat hal tersebut, yaitu hak, kewajiban, kewenangan, dan tanggung jawab dari kedua belah pihak, yaitu tenaga kerja dan majikan/ pengusaha. ${ }^{49}$ Terkait dengan subjek hukum dalam suatu hubungan kerja apabila dikaitkan dengan Pasal 1 angka 15 Undang-Undang Nomor 13 Tahun 2003 adalah pengusaha dan pekerja/buruh dengan tidak memasukan pemberi kerja, berarti tidak mempunyai konsekuensi apaapa jika dikaitkan dengan Pasal 1 angka 14 Undang-Undang Nomor 13 Tahun 2003, karena menghilangkan kata pemberi kerja berdampak pada belum terlindunginya tenaga kerja yang bekerja pada selain pengusaha atau yang bekerja di sektor informal (di luar hubungan kerja).

Perlindungan hukum bagi tenaga kerja menurut Mohd. Syaufii Syamsudin harus dilakukan sejak sebelum dalam hubungan kerja, selama dalam hubungan kerja, dan setelah hubungan kerja berakhir..50 Hubungan kerja yang dilakukan antara tenagakerjadenganpengusahayangselama ini di Indonesia, belum mencerminkan adanya perlindungan hukum seperti yang diutarakan oleh Mohd. Syaufii Syamsudin. Pada saat sebelum hubungan kerja

\footnotetext{
48 Toto Tohir Suriaatmadja, “Aspek Perlindungan Hukum dalam Hukum Ketenagakerjaan”, Makalah Seminar Nasional yang Diselenggarakan Program Doktor Ilmu Hukum Pascasarjana UNISBA, Savoy Homann Bidakara Hotel, Bandung, 23 November 2013, hlm. 2.

49 Ibid.

50 Mohd. Syaufii Syamsudin, Norma Perlindungan dalam Hubungan Industrial, Sarana Bhakti Persada, Jakarta, 2004, hlm. 8.
} 
berlangsung, perlindungan hukum yang diberikan pemerintah kepada tenaga kerja belum maksimal, karena belum adanya regulasi atau peraturan perundangundangan yang mengatur hak tenaga kerja pada saat sebelum terjadinya hubungan kerja. Perlindungan hukum bagi tenaga kerja sebelum terjadinya hubungan kerja yang sangat prinsip belum dilaksanakan oleh pemerintah adalah adanya ketentuan peraturan perundang-undangan yang hanya membatasi hubungan kerja pada hubungan yang didasarkan pada perjanjian kerja.

Rumusan perjanjian kerja sangat membatasi subjek hukum, yaitu pekerja yang bekerja pada pengusaha dan pengusaha yang menjalankan perusahaan, baik miliknya atau bukan. Sementara itu, apabila ada orang yang mempekerjakan orang lain, tetapi tidak sedang dalam menjalankan perusahaan, maka orang lain itu bukan pekerja yang dilindungi oleh Undang-Undang Nomor 13 Tahun 2003. Tampak sekali perumusan UndangUndang Nomor 13 Tahun 2003 kurang memahami konsep hukum mengenai subjek hukum hubungan kerja, seharusnya bukan pengusaha yang menjadi subjek hukum tetapi pemberi kerja. Pengertian pemberi kerja adalah mencakup siapapun yang sedang mempekerjakan orang lain untuk memenuhi kepentingannya dengan membayar upah. Makna menjalankan kepentingan di sini harus merupakan suatu kepentingan yang tidak bertentangan dengan dasar filosofis manusia yang secara kodrati tidak boleh ada unsur merugikan orang lain. Dengan demikian, suatu kepentingan untuk menjalankan pekerjaan harus sesuai dengan kepatutan, ketertiban umum, dan peraturan perundang-undangan. ${ }^{51}$

Kandungan materiil dari kepentingan yang letaknya sebagai subjek hukum dalam hubungan kerja harus benarbenar menguntungkan kedua belah pihak, baik pemberi kerja maupun pekerja. Selama ini, makna perlindungan hukum bagi pekerja seolah hanya ada di dalam peraturan perundang-undangan tanpa ada harapan untuk pelaksanaannya. Perlindungan hukum bagi pekerja memang harus menitikberatkan pada kepentingan pekerja, hal ini karena negara mempunyai kewajiban untuk memberikan perlindungan dan jaminan pelaksanaan hak kepada pekerja, karena secara sosial ekonomi kedudukan pekerja adalah lemah, sehingga harus dilindungi dari kekuasaan pemberi kerja. Apabila dikembalikan kepada hakikat hukum ketenagakerjaan adalah hukum yang memberikan perlindungan kepada tenaga kerja, pemerintah harus membuat kondisi perlindungan itu dapat terlaksana. Pemerintah dapat melakukan 2 (dua) hal, yaitu pembuatan norma hukum ketenagakerjaan yang terwujud dalam regulasinya serta adanya jaminan pemerintah dapat membuat suatu regulasi yang dapat memfungsikan pegawai pengawas ketenagakerjaan. ${ }^{52}$

Berdasarkan ketentuan Pasal 1 angka 15 jo. Pasal 50 - Pasal 66 Undang-Undang Nomor 13 Tahun 2003 subjek hukum

51 Pasal 52 ayat (1) huruf d Undang-Undang Nomor 13 Tahun 2003 tentang Ketenagakerjaan.

52 Asri Wijayanti, Menggugat ... Op. Cit., hlm. 103. 
dari hubungan kerja adalah pengusaha dengan pekerja/buruh, sehingga batasan subjek hukum berdasarkan ketentuan di atas sangat sempit. Batasan subjek hukum akan berbeda apabila didasarkan pada ketentuan Pasal 1 angka 14 UndangUndang Nomor 13 Tahun 2003, yaitu perjanjian kerja adalah perjanjian antara pekerja/buruh dengan pengusaha atau pemberi kerja yang memuat syarat-syarat kerja, hak, dan kewajiban para pihak.

Apabila dilakukan perbandingan antara ketentuan Pasal 1 angka 14 dengan ketentuan Pasal 1 angka 15 jo. Pasal 50 Pasal 66 Undang-Undang Nomor 13 Tahun 2003, maka terdapat perbedaan akibat hukumnya. Unsur-unsur dari ketentuan
Pasal 1 angka 14 Undang-Undang Nomor 13 Tahun 2003 adalah subjek hukum perjanjian kerja terdiri dari pekerja/buruh dengan pengusaha atau pemberi kerja, sedangkan yang menjadi objek perjanjian kerjanya adalah syarat-syarat kerja, hak, dan kewajiban para pihak. Unsur-unsur tersebut berbeda dengan ketentuan Pasal 1 angka 15 jo. Pasal 50 - Pasal 66 Undang-Undang Nomor 13 Tahun 2003 dengan subjek hukum perjanjian kerjanya adalah pengusaha dengan pekerja/buruh, sedangkan yang menjadi objek perjanjian kerjanya adalah pekerjaan, upah, dan perintah. Apabila hal tersebut dilakukan perbandingan ke dalam bentuk tabel akan tampak sebagai berikut: ${ }^{53}$

Tabel 1.

Perbandingan Pasal 1 angka 14 dengan Pasal 1 angka 15, Pasal 50, dan Pasal 66 Undang-Undang Nomor 13 Tahun 2003

\begin{tabular}{|l|l|l|l|}
\hline \multicolumn{1}{|c|}{$\begin{array}{c}\text { Unsur- } \\
\text { unsur }\end{array}$} & \multicolumn{1}{c|}{ Pasal 1 angka 14 } & $\begin{array}{l}\text { Pasal 1 angka 15 } \\
\text { jo. Pasal 50 - 66 }\end{array}$ & \multicolumn{1}{c|}{ Perbedaan } \\
\hline $\begin{array}{l}\text { Subjek } \\
\text { hukum }\end{array}$ & $\begin{array}{l}\text { Pekerja/buruh } \\
\text { dengan pengusaha } \\
\text { atau pemberi kerja }\end{array}$ & $\begin{array}{l}\text { Pengusaha dengan } \\
\text { pekerja/buruh }\end{array}$ & $\begin{array}{l}\text { Pemberi kerja } \\
\text { lebih luas daripada } \\
\text { pengusaha }\end{array}$ \\
\hline $\begin{array}{l}\text { Objek } \\
\text { hukum }\end{array}$ & $\begin{array}{l}\text { Syarat-syarat kerja, } \\
\text { hak, dan kewajiban } \\
\text { para pihak }\end{array}$ & $\begin{array}{l}\text { Pekerjaan, upah, } \\
\text { dan perintah }\end{array}$ & $\begin{array}{l}\text { Perintah menunjukkan } \\
\text { hubungan sub ordinasi }\end{array}$ \\
\hline
\end{tabular}

Berdasarkan tabel di atas, dengan pemberi kerja, bahwa menurut menunjukkan adanya pertentangan batasan dua pengertian yang diberikan oleh pembuat undang-undang, yaitu subjek hukum pengusaha dengan pemberi kerja, adanya unsur perintah di dalam perjanjian kerja. Sementara itu, apabila dianalisis batasan pengusaha berbeda Pasal 1 angka 4 Undang-Undang Nomor 13 Tahun 2003 dikemukakan, bahwa pemberi kerja adalah orang perseorangan, pengusaha, badan hukum, atau badanbadan lainnya yang mempekerjakan tenaga kerja dengan membayar upah atau imbalan dalam bentuk lain, sedangkan tenaga kerja dirumuskan sebagai setiap

53 Ibid., hlm. 105. 
orang yang mampu melakukan pekerjaan guna menghasilkan barang dan/atau jasa, baik untuk memenuhi kebutuhan sendiri maupun untuk masyarakat.

Berdasarkan ketentuan di atas, dapat dianalisis adanya perbedaan penafsiran mengenai batasan pengertian pekerja, apabila ketentuan Pasal 1 angka 3, Pasal 1 angka 5, Pasal 1 angka 6, Pasal 1 angka 15 Undang-Undang Nomor 13 Tahun 2003 dengan ketentuan Pasal 1 angka 3, Pasal 1 angka 14 Undang-Undang Nomor 13 Tahun 2003, bahwa batasan pengertian pekerja, apabila didasarkan pada ketentuan Pasal 1 angka 3, Pasal 1 angka 5, Pasal 1 angka 6, Pasal 1 angka 15 Undang-Undang Nomor 13 Tahun 2003 sangat sempit dan terbatas hanya meliputi orang yang bekerja pada pengusaha saja, bukan pada pemberi kerja, sedangkan ketentuan Pasal 1 angka 3, Pasal 1 angka 14 Undang-Undang Nomor 13 Tahun 2003 dikenal subjek hukum pemberi kerja yang dalam Pasal 1 angka 4 Undang-Undang Nomor 13 Tahun 2003 pengertiannya lebih luas daripada pengusaha, demikian juga dengan pengertian tenaga kerja lebih luas daripada pekerja.

Apabila mengkaji hakikat dari Undang-Undang Nomor 13 Tahun 2003 yang menyandang nama besar sebagai Undang-Undang Ketenagakerjaan adalah suatu undang-undang yang memberikan perlindungan pada tenaga kerja bukan pada pekerja. Hal ini dapat diketahui pada dasar filosofis terbentuknya UndangUndang Nomor 13 Tahun 2003 yang dapat dilihat dari konsiderans menimbang huruf a, huruf b, dan huruf c sebagai berikut:

“a. bahwa pembangunan nasional dilaksanakan dalam rangka pembangunan manusia Indonesia seutuhnya dan pembangunan masyarakat Indonesia seluruhnya untuk mewujudkan masyarakat yang sejahtera, adil, makmur, yang merata, baik materiil maupun spiritual berdasarkan Pancasila dan UndangUndang Dasar Negara Republik Indonesia Tahun 1945;

b. bahwa dalam pelaksanaan pembangunan nasional, tenaga kerja mempunyai peranan dan kedudukan yang sangat penting sebagai pelaku dan tujuan pembangunan;

c. bahwa sesuai dengan peranan dan kedudukan tenaga kerja, diperlukan pembangunan ketenagakerjaan untuk meningkatkan kualitas tenaga kerja dan peran sertanya dalam pembangunan serta peningkatan perlindungan tenaga kerja dan keluarganya sesuai dengan harkat dan martabat kemanusiaan".

Berdasarkan konsiderans huruf a, huruf b, dan huruf c Undang-Undang Nomor 13 Tahun 2003, dapat diketahui bahwa pembentuk undang-undang menghendaki dibuatnya suatu aturan hukum yang memberikan perlindungan hukum kepada tenaga kerja, mengingat peranan dan kedudukannya yang sangat penting sebagai pelaku dan tujuan pembangunan.

Dasar filosofis tersebut dijelaskan lebih lanjut mengenai pembangunan ketenagakerjaan dalam Penjelasan Umum Undang-Undang Nomor 13 Tahun 2003, sebagai berikut:

“... sebagai bagian integral dari pembangunan nasional berdasarkan 
Pancasila dan Undang-Undang Dasar

Negara Republik Indonesia Tahun 1945, dilaksanakan dalam rangka pembangunan manusia Indonesia seutuhnya dan pembangunan masyarakat Indonesia seluruhnya untuk meningkatkan harkat, martabat, dan harga diri tenaga kerja, serta mewujudkan masyarakat sejahtera, adil, makmur, dan merata, baik materiil maupun spiritual. Pembangunan ketenagakerjaan harus diatur sedemikian rupa, sehingga terpenuhi hak-hak dan perlindungan yang mendasar bagi tenaga kerja dan pekerja/buruh serta pada saat yang bersamaan dapat mewujudkan kondisi yang kondusif bagi pengembangan dunia usaha".

Perlindungan hukum bagi tenaga kerja merupakan perwujudan dari usaha untuk memajukan kesejateraan umum, tetapi dasar filosofi yang ditetapkan oleh pembuat Undang-Undang Nomor 13 Tahun 2003 ini, ternyata tidak konsisten. Hal ini tampak dalam rumusan konsiderans menimbang huruf d Undang-Undang Nomor 13 Tahun 2003 sebagai berikut:

"Perlindungan terhadap tenaga kerja dimaksudkan untuk menjamin hak-hak dasar pekerja/buruh dan menjamin kesamaan kesempatan kerja serta perlakuan tanpa diskriminasi atas dasar apapun untuk mewujudkan kesejahteraan pekerja/ buruh dan keluarganya dengan tetap memperhatikan perkembangan kemajuan dunia usaha".
Konsiderans menimbang huruf $d$ Undang-Undang Nomor 13 Tahun 2003 tersebut, membatasi pengertian tenaga kerja hanya mencakup pekerja saja bukan tenaga kerja, hal ini menunjukkan adanya pertentangan norma antara konsiderans menimbang huruf $a$, huruf $b$, dan huruf c dengan konsiderans huruf d UndangUndang Nomor 13 Tahun 2003. Lebih lanjut, dasar filosofi yang ada pada konsiderans menimbang huruf a, huruf b, dan huruf c tersebut tidak diterapkan dalam pasal-pasal Undang-Undang Nomor 13 Tahun 2003, khususnya hanya membatasi pekerja yang bekerja pada pengusaha saja, bukan pekerja yang bekerja pada pemberi kerja. Ini berarti substansi Undang-Undang Nomor 13 Tahun 2003 hanya menitikberatkan pada pengaturan hubungan kerja di sektor formal.

Pengaturan masalah ketenagakerjaan dalam Undang-Undang Nomor 13 Tahun 2003 tentang Ketenagakerjaan yang menitikberatkan pada aspek hubungan kerja, berarti tidak sejalan dengan ruang lingkup hukum ketenagakerjaan yang mencakup segala hal yang berhubungan dengan tenaga kerja sebelum, selama, dan sesudah masa kerja. Oleh karena itu, terhadap Undang-Undang Nomor 13 Tahun 2003 tentang Ketenagakerjaan diusulkan harus segera direvisi dan memasukan mengenai pengaturan tentang hubungan ketenagakerjaan, baik di sektor formal maupun informal, atau segera diganti dengan Undang-Undang Ketenagakerjaan yang baru. Hal ini mengingat beberapa pasal yang ada dalam Undang-Undang Nomor 13 Tahun 2003 tentang Ketenagakerjaan telah dilakukan 
uji materiil oleh Mahkamah Konstitusi sebanyak 11 kali, sehingga pasal-pasal yang telah diuji tersebut dinyatakan bertentangan dengan Undang-Undang Dasar Negara Republik Indonesia Tahun 1945 dan dinyatakan tidak memiliki kekuatan mengikat adalah sebagai berikut: ${ }^{54}$

a. Putusan Mahkamah Konstitusi Nomor 012/PUU-I/2003 tentang pengujian Pasal 158, Pasal 159, Pasal 160 ayat (1), Pasal 170, Pasal 171, Pasal 186 Undang-Undang Nomor 13 Tahun 2003 tentang Ketenagakerjaan.

b. Putusan Mahkamah Konstitusi Nomor 115/PUU-VII/2009 tentang pengujian Pasal 120 ayat (1), ayat (2), dan ayat (3) Undang-Undang Nomor 13 Tahun 2003 tentang Ketenagakerjaan.

c. Putusan Mahkamah Konstitusi Nomor 61/PUU-VIII/2010 tentang pengujian Pasal 1 butir 22, Pasal 88 ayat (3) huruf a, Pasal 90 ayat (2), Pasal 160 ayat (3) dan ayat (6), Pasal 162 ayat (1) hurufa, Pasal 171 Undang-Undang Nomor 13 Tahun 2003 tentang Ketenagakerjaan.

d. Putusan Mahkamah Konstitusi Nomor 19/PUU/2011 tentang Pengujian Pasal 164 ayat (3) Undang-Undang Nomor 13 Tahun 2003 tentang Ketenagakerjaan.

e. Putusan Mahkamah Konstitusi Nomor 27/PUU/2011 tentang pengujian Pasal 65 ayat (7), dan Pasal 66 ayat (2) Undang-Undang Nomor 13 Tahun 2003 tentang Ketenagakerjaan.

f. Putusan Mahkamah Konstitusi Nomor 37/PUU/2011 tentang pengujian
Pasal 155 ayat (2) Undang-Undang Nomor 13 Tahun 2003 tentang Ketenagakerjaan.

g. Putusan Mahkamah Konstitusi Nomor 58/PUU-VII/2011 tentang pengujian 169 ayat (1) huruf c Undang-Undang Nomor 13 Tahun 2003 tentang Ketenagakerjaan.

h. Putusan Mahkamah Konstitusi Nomor 100/PUU-VII/2012 tentang pengujian Pasal 96 Undang-Undang Nomor 13 Tahun 2003 tentang Ketenagakerjaan.

i. Putusan Mahkamah Konstitusi Nomor 117/PUU-VII/2012 tentang pengujian Pasal 163 ayat (1) Undang-Undang Nomor 13 Tahun 2003 tentang Ketenagakerjaan.

j. Putusan Mahkamah Konstitusi Nomor 69/PUU-VII/2013 tentang pengujian Pasal 160 ayat (3) dan ayat (7), Pasal 162 ayat (1) dan ayat (2) UndangUndang Nomor 13 Tahun 2003 tentang Ketenagakerjaan.

k. Putusan Mahkamah Konstitusi Nomor 96/PUU-VII/2013 tentang pengujian Pasal 59 ayat (7), Pasal 65 ayat (8), dan Pasal 66 ayat (4) Undang-Undang Nomor 13 Tahun 2003 tentang Ketenagakerjaan.

Apabila mencermati lebih jauh, sebenarnya Indonesia pernah mempunyai aturan yang berkaitan dengan pekerja informal, yaitu Undang-Undang Nomor 25 Tahun 1997 tentang Ketenagakerjaan yang keberadaannya menimbulkan perdebatan, sehingga ditunda masa berlakunya oleh Undang-Undang Nomor 11 Tahun 1998 jo. Peraturan Pemerintah Pengganti Undang-

54 Ujang Charda S., "Karakteristik Undang-Undang Ketenagakerjaan dalam Perlindungan Hukum Terhadap Tenaga Kerja", Jurnal Wawasan Hukum, Vol. 32 No. 1, STHB, Bandung, Maret 2015, hlm. 18-19. 
Undang Nomor 3 Tahun 2000 jo. UndangUndang Nomor 28 Tahun 2000 sampai tanggal 1 Oktober 2002 yang akhirnya tidak berlaku dan dinyatakan dicabut dengan diundangkannya Undang-Undang Nomor 13 Tahun 2003.

Terkait dengan ruang lingkup pengaturan hukum ketenagakerjaan, dalam Undang-Undang Nomor 25 Tahun 1997 ada rumusan mengenai hubungan kerja sektor formal maupun informal sebagaimana terumus dalam Pasal 1 angka 7 Undang-Undang Nomor 25 Tahun 1997 yang dirumuskan sebagai berikut:

"Hubungan kerja sektor formal adalah suatu hubungan kerja yang terjalin antara pengusah dengan pekerja berdasarkan perjanjian kerja, baik untuk waktu tertentu maupun untuk waktu tidak tertentu yang mengandung adanya unsur pekerjaan, upah, dan perintah".

Selanjutnya, dalam Pasal 1 angka 33 Undang-Undang Nomor 25 Tahun 1997 diatur mengenai hubungan kerja sektor informal yang dirumuskan sebagai berikut:

"Hubungan kerja sektor formal adalah suatu hubungan kerja yang terjalin antara pekerja dan orang perseorangan atau beberapa orang yang melakukan usaha bersama yang tidak berbadan hukum atas dasar saling percaya dan sepakat dengan menerima upah dan/ atau imbalan atau bagi hasil".

Selain itu, terdapatjuga rumusan usaha sektor informal berdasarkan ketentuan Pasal 1 angka 31 Undang-Undang Nomor 25 Tahun 1997 yang dirumuskan sebagai berikut:
"Usaha sektor informal adalah kegiatan orang perseorangan atau keluarga atau beberapa orang yang melaksanakan usaha bersama untuk melakukan kegiatan ekonomi atas dasar kepercayaan dan kesepakatan, dan tidak berbadan hukum".

Di samping itu, terdapat rumusan mengenai pekerja sektor informal yang pengertiannya diatur dalam Pasal 1 angka 32 Undang-Undang Nomor 25 Tahun 1997 dengan rumusan sebagai berikut:

"Pekerja sektor informal adalah tenaga kerja yang bekerja dalam hubungan kerja sektor informal dengan menerima upah dan/atau imbalan".

Sementara itu, dirumuskan pula mengenai pengertian pekerja (sektor formal) dalam Pasal 1 angka 3 UndangUndang Nomor 25 Tahun 1997 sebagai berikut: "Pekerja adalah tenaga kerja yang bekerja di dalam hubungan kerja pada pengusaha dengan menerima upah".

Di dalam rumusan tersebut, pengertian pekerja sektor informal maupun formal merupakan bagian dari pengertian tenaga kerja yang dirumuskan dalam Pasal 1 angka 2 Undang-Undang Nomor 25 Tahun 1997 sebagai berikut:

"Tenaga kerja adalah setiap orang lakilaki atau wanita yang sedang dalam dan/atau akan melakukan pekerjaan, baik di dalam hubungan kerja maupun di luar hubungan kerja guna menghasilkan barang atau jasa untuk memenuhi kebutuhan masyarakat".

Pengaturan lebih lanjut mengenai hubungan kerja sektor informal, diatur 
secara khusus dalam Bab XI tentang Tenaga Kerja di dalam Hubungan Kerja Sektor Informal dan di Luar Hubungan Kerja, Pasal 158 sampai dengan Pasal 160 Undang-Undang Nomor 25 Tahun 1997 yang di dalamnya dirumuskan mengenai hak-hak tenaga kerja yang bekerja di luar hubungan kerja, yaitu:

a. Jaminan sosial tenaga kerja.

b. Keselamatan kerja dan melakukan pekerjaan.

c. Pembinaan dan pengembangan melalui memasyarakatkan dan memberdayakan tenaga kerja bekerja mandiri, meningkatkan keterampilan teknis dan manajerial tenaga kerja mandiri, peningkatan keterampilan dan keahlian kerja melalui lembaga pendidikan dan pelatihan, serta konsultasi bagi tenaga kerja bekerja mandiri, dan penyediaan tenaga penyuluh.

d. Perlindungan dan peningkatan kesejahteraan tenaga kerja.

Ketentuan hukum mengenai hubungan kerja sektor informal yang diatur dalam Undang-Undang Nomor 25 Tahun 1997, apabila menerapkan asas hukum lex specialis derogat legi generalis, maka ketentuan ini sudah tidak berlaku. Berdasarkan ketentuan Pasal 192 UndangUndang Nomor 13 Tahun 2003, yaitu Undang-Undang Nomor 28 Tahun 2000 tentang Penetapan Peraturan Pemerintah Pengganti Undang-Undang Nomor 3 Tahun 2000 tentang Perubahan Atas Undang-Undang Nomor 11 tahun 1998 tentang Perubahan Berlakunya UndangUndang Nomor 25 Tahun 1997 tentang
Ketenagakerjaan menjadi Undang-Undang dinyatakan tidak berlaku lagi. Asas lex specialis derogat legi generalis diterapkan apabila ada peraturan yang kemudian dan peraturan yang lebih terdahulu dan mengatur tentang hal yang sama, maka yang berlaku adalah peraturan yang kemudian.

Berkaitan dengan hubungan kerja sektor informal, apabila ketentuan yang termuat di dalam peraturan perundangundangan yang lama tersebut tidak bertentangan dengan landasan filosofis peraturan perundang-undangan yang baru, harus dinyatakan bahwa ketentuan itu tetap berlaku melalui peralihan peraturan perundang-undangan yang baru. Menurut Peter Mahmud Marzuki, apabila peraturan perundang-undangan (Undang-Undang Nomor 13 Tahun 2003) tidak mengaturnya terhadap keadaan ini yang dibutuhkan untuk situasi yang sedang dihadapi, ketentuan tersebut justru termuat di dalam peraturan perundangundangan yang telah digantikan. Apabila ketentuan yang termuat dalam peraturan perundang-undangan yang lama tidak bertentangan dengan landasan filosofis peraturan perundang-undangan yang baru, harus dapat dinyatakan bahwa ketentuan itu tetap berlaku melalui aturan peralihan peraturan perundang-undangan yang baru. ${ }^{55}$

Berdasarkan uraian di atas, subjek hukum dalam hubungan kerja seharusnya terdiri dari pemberi kerja dengan pekerja/ buruh, bukan antara pengusaha dengan pekerja. Pemberi kerja adalah orang yang memberikan pekerjaan, jadi tidak

55 Peter Mahmud Marzuki, Penelitian Hukum, Prenada Media Group, Jakarta, 2005, hlm. 101. 
tergantung pada orang yang menjalankan perusahaan dan meliputi kerja formal dan informal. Apabila konsep hukum dari hubungan hukum menjadi hubungan kerja sebagai hubungan antara pemberi kerja dengan pekerja/buruh berdasarkan perjanjian kerja, maka perlindungan hukum terhadap pekerja/buruh semakin dapat terwujud.

Dengan demikian, konsep hubungan kerja mengalami pergeseran, batasan subjek hukum hanya diartikan secara sempit pada pekerja/buruh dengan pengusaha saja, bukan pada pemberi kerja membawa akibat kurangnya perlindungan hukum. Pekerja/buruh yang dilindungi oleh Undang-Undang Nomor 13 Tahun 2003 tentang Ketenagakerjaan hanya pekerja/buruh formal yang bekerja pada pengusaha, sedangkan pekerja/buruh yang bekerja pada pemberi kerja selain pengusaha tidak mendapat perlindungan hukum, dan pekerja/buruh informal juga tidak mendapat perlindungan hak-haknya sebagai pekerja/buruh. ${ }^{56}$

Hal tersebut tidak sejalan dengan pergeseran hukum perburuhan ke hukum ketenagakerjaan, dan semangat dari pembentukan hukum ketenagakerjaan yang seharusnya dalam regulasi formalnya melalui UndangUndang Nomor 13 Tahun 2003 tentang Ketenagakerjaan mencerminkan bentuk perlindungan hukum bagi segenap tenaga kerja sebagaimana prinsip umum perlindungan dalam ruang lingkup hukum ketenagakerjaan yang memberikan perlindungan pada tenaga kerja yang tidak hanya pekerja/buruh formal yang bekerja pada pengusaha saja, tetapi meliputi semua orang yang bekerja, baik pada negara maupun yang bekerja pada orang lain sebagai pengusaha dan bukan pengusaha.

Berdasarkan uraian di atas, pola hubungan kerja bagi anak yang melakukan pekerjaan harus didasarkan pada perjanjian kerja yang dibuat secara tertulis antara pengusaha dengan orang tua/walinya yang mempunyai unsur pekerjaan, upah, dan perintah ${ }^{57}$ dengan menempatkan kedudukan anak dalam lingkungan hukum sebagai subjek hukum yang ditentukan dari bentuk dan sistem hukum terhadap anak sebagai kelompok masyarakat yang berada dalam status hukum yang tergolong tidak mampu (lemah). Maksud tidak mampu (lemah), karena kedudukan akal dan pertumbuhan fisik yang sedang berkembang dalam diri anak yang bersangkutan. ${ }^{58}$

Dengan demikian, hubungan kerja terjadi karena adanya perjanjian kerja antara pekerja/buruh dan pengusaha yang memuat syarat-syarat kerja, hak, dan kewajiban para pihak. ${ }^{59}$ Ketentuan perjanjian kerja yang ada dalam UndangUndang Nomor 13 Tahun 2003 tentang Ketenagakerjaan merupakan bagian dari hubungan kerja, bukan merupakan bagian dari hukum perjanjian. Oleh karena itu, ketentuan perjanjian kerja bukan hukum pelengkap (aanvullend recht), sehingga

\footnotetext{
$56 \quad$ Koko Kosidin, Aspek-aspek Hukum ... Op. Cit., hlm. 306-307.

57 Pasal 1 angka 15 Undang-Undang Nomor 13 Tahun 2003 tentang Ketenagakerjaan.

58 Elfrianto, "Hak atas Pendidikan dan Perlindungan Hukum Pekerja Anak", Jurnal Madani Vol. 8 No. 2 , FKIP Universitas Muhammadiyah, Sumut, 2007, hlm. 256.

59 Pasal 1 angka dan Pasal 50 Undang-Undang Nomor 13 Tahun 2003 tentang Ketenagakerjaan.
} 
ketentuan perjanjian kerja bersifat memaksa, artinya ketentuan perjanjian kerja dalam hukum ketenagakerjaan bersifat wajib untuk ditaati dan diikuti. ${ }^{60}$

Para pihak dalam perjanjian kerja tidak dapat membuat perjanjian kerja yang menyimpang dari ketentuan peraturan perundang-undangan ketenagakerjaan, sehingga tidak dapat dikesampingkan oleh para pihak dalam membuat perjanjian kerja, karena perjanjian kerja merupakan bagi dari hukum ketenagakerjaan bukan bagian dari hukum perjanjian. Hukum perjanjian yang mengatur ketentuan umum, sepanjang tidak diatur oleh hukum ketenagakerjaan, berlaku dalam perjanjian kerja, tetapi bila Undang-Undang Nomor 13 Tahun 2003 tentang Ketenagakerjaan telah mengaturnya, maka ketentuan tersebut bersifat memaksa dan tidak dapat dikesampingkan. ${ }^{61}$

Menurut Pasal 52 Undang-Undang Nomor 13 Tahun 2003 tentang Ketenagakerjaan, bahwa perjanjian kerja dibuat atas dasar:

a. Kesepakatan kedua belah pihak

Melihat awal penerapan hukum dalam perjanjian kerja dimulai dengan perjanjian kerja, Undang-Undang Nomor 13 Tahun 2003 tentang Ketenagakerjaan telah mendetilkan syarat sahnya perjanjian dalam Pasal 1320 KUH Perdata ke dalam Pasal 51, dan Pasal 52. Pasal 51 menyatakan, bahwa perjanjian kerja dapat dibuat secara lisan maupun tertulis, kalau undang-undang mengharuskan dibuat secara tertulis, berarti tidak boleh lisan, hal ini akan menyebabkan kebatalan dari perjanjian kerja.

Sementara itu, rumusan Pasal 52 Undang-Undang Nomor 13 Tahun 2003 tentang Ketenagakerjaan hampir persis dengan Pasal 1320 KUH Perdata, hanya saja rumusannya berbeda pada ayat (1) hurup c, yaitu adanya pekerjaan yang diperjanjikan, sedangkan rumusan Pasal 1320 hurup c KUH Perdata, yaitu suatu hal tertentu dan bersifat objektif, karena dirumuskan secara umum untuk dasar seluruh perjanjian dalam masyarakat. ${ }^{62}$

Selanjutnya, dalam penjelasan Pasal 52 Undang-Undang Nomor 13 Tahun 2003 tentang Ketenagakerjaan, dikatakan bahwa kesepakatan adalah cukup jelas. Apakah yang dimaksud dengan kesepakatan memang sudah cukup jelas bagi semua pihak? Memang sukar memberikan penjelasan tentang kesepakatan ini, misalnya seorang pengusaha berkata kepada seorang tenaga kerja, bahwa di perusahaannya ada lowongan pekerjaan dan mengatakan apakah orang tersebut mau bekerja di perusahaannya. Lalu orang tersebut menyatakan mau, apakah dalam hal ini telah terjadi kesepakatan? Jawabannya pasti belum terjadi kesepakatan, karena mengenai apa yang disepakati itu belum jelas, seperti pekerjaannya apa dan berapa pembayarannya belum disepakati.

\footnotetext{
60 Hardijan Rusli, Hukum Ketenagakerjaan Berdasarkan UU No. 13 Tahun 2003 tengang Ketenagakerjaan dan Peraturan Terkait Lainnya, Ghalia Indonesia, Bogor, 2011, hlm. 51.

61 Ibid.

62 Toto Tohir Suriaatmadja, “Aspek Perlindungan ...., Op. Cit., hlm. 5.
} 
Inti perjanjian kerja adalah suatu kesepakatan terjadi kalau pihak pengusaha setuju untuk mempekerjakan tenaga kerja tersebut dengan pekerjaan tertentu yang sudah diberitahukan kepada tenaga kerja dan tenaga kerja itu setuju untuk menerima pekerjaan dengan jumlah pembayaran tertentu yang disepakati. Mengenai hal-hal lain, seperti jam kerja (kecuali untuk jam kerja malam atau di luar kebiasaan) yang sudah diatur oleh undang-undang tidak mencakup sebagai hal yang harus disepakati dahulu agar terjadi kesepakatan.

b. Kemampuan dan kecakapan melakukan perbuatan hukum

Di dalam penjelasan Pasal 52 Undang-Undang Nomor 13 Tahun 2003 tentang Ketenagakerjaan dijelaskan, bahwa kemampuan dan kecakapan adalah para pihak yang mampu atau cakap menurut hukum untuk membuat perjanjian atau dengan kata lain cakap untuk membuat perikatan-perikatan, kecuali oleh undang-undang dinyatakan tidak cakap sebagaimana diatur dalam Pasal 1330 KUH Perdata, yaitu: ${ }^{63}$
1) Anak yang belum dewasa.

2) Mereka yang ditaruh di bawah pengampuan.

3) Orang-orang perempuan, dalam hal-hal yang ditetapkan oleh undang-undang.

Berdasarkan ketiga subjek hukum tersebut, salah satunya adalah orang yang belum dewasa merupakan orang yang tidakcakap melakukan perbuatan hukum atau perikatan disebabkan: ${ }^{64}$

1) Orang belum dewasa itu umumnya belum memiliki harta kekayaannya sendiri karena belum bekerja. Oleh sebab itu, belum mampu untuk dapat memberikan pertanggungjawaban atas perikatan yang dibuatnya yang secara hukum dijamin dengan harta pribadi dari pihak perjanjian.

2) Orang yang belum dewasa, karena keadaan jiwa atau pribadinya belum stabil/mantap, sehingga dianggap masih belum dapat mengambil keputusan dengan benar.

Tingkat kecakapan dan kedewasaan seseorang secara

63 Khusus mengenai kriteria ketiga, yaitu bagi seorang perempuan, seperti disebutkan di atas bertentangan dengan Pasal 27 ayat (1) UUD 1945, Pasal 31 Undang-Undang Nomor 1 Tahun 1974 tentang Perkawinan, kemudian dalam praktik diperkuat dengan adanya Surat Edaran Mahkamah Agung (SEMA) Republik Indonesia Nomor 3 Tahun 1963 sekalipun secara hierarki menurut kaum positivis, sebuah SEMA tidak mungkin menghapuskan suatu undang-undang, apalagi setingkat kitab undangundang, tetapi dalam kenyataannya SEMA itulah yang diikuti dalam praktik peradilan. Terlepas dari pro dan kontra kewenangan suatu SEMA membatalkan suatu undang-undang, tetapi hakikat terdalam yang diperoleh dari SEMA tersebut adalah adanya tekad keras Mahkamah Agung waktu itu untuk mengejar ketertinggalan undang-undang melalui putusan-putusan yang lebih hidup dan lebih sesuai dengan perkembangan dan tuntutan masyarakat. Hakim Agung yang ada sekarang diharapkan tidak lagi memfungsikan diri sekedar sebagai terompet undang-undang, melainkan benar-benar sebagai living interpretator dari rasa keadilan masyarakat. Lihat Subekti, Hukum Perjanjian, Intermasa, Jakarta, 1979, hlm. 13. Lihat juga Achmad Ali, Keterpurukan Hukum di Indonesia (Penyebab dan Solusinya), Ghalia Indonesia, Jakarta, 2005, hlm. 12.

64 Hardijan Rusli, Op. Cit., hlm. 53. 
kuantitatif dapat ukur dari usia sebagaimana dirumuskan Pasal 1 angka 26 Undang-Undang Nomor 13 Tahun 2003 tentang Ketenagakerjaan, bahwa anak adalah setiap orang yang berumur di bawah 18 (delapan belas) tahun. Oleh karena itu, menurut Pasal 68 Undang-Undang Nomor 13 Tahun 2003 tentang Ketenagakerjaan, bahwa pengusaha dilarang mempekerjakan anak dengan pengecualian yang dipersyaratkan bagi anak yang berumur antara 13 (tiga belas) tahun sampai dengan 15 (lima belas) tahun sebagaimana diatur dalam Pasal 69 ayat (1) Undang-Undang Nomor 13 Tahun 2003 tentang Ketenagakerjaan.

Pengecualian tersebut adalah untuk melakukan pekerjaan-pekerjaan sebagai berikut:

1) Pekerjaan ringan sepanjang tidak mengganggu perkembangan dan kesehatan fisik, mental, dan sosial sebagaimana diatur dalam Pasal 69 ayat (2) UndangUndang Nomor 13 Tahun 2003 tentang Ketenagakerjaan dengan persyaratan:

a) Izin tertulis dari orang tua atau wali.

b) Perjanjian kerja antara pengusaha dengan orang tua atau wali (di sini yang menjadi pihak dalam perjanjian kerja adalah orang tua/wali anak, bukan anak itu sendiri).

c) Waktu kerja maksimum 3 jam.

d) Dilakukan pada siang hari dan tidak mengganggu waktu sekolah. e) Keselamatan dan kesehatan kerja.

f) Adanya hubungan kerja yang jelas.

g) Menerima upah sesuai dengan ketentuan yang berlaku.

Di dalam praktiknya, pelaksanaan hubungan kerja antara pengusaha dengan tenaga kerja anak ditemukan beberapa bentuk penyimpangan persyaratan kerja sebagai berikut:

a) Tidak ada izin tertulis orang tua/wali

Pasal 69 ayat (2) huruf a Undang-Undang Nomor 13 Tahun 2003 tentang Ketenagakerjaan, bahwa apabila anak akan bekerja terlebih dahulu harus memperoleh izin tertulis dari orang tua atau walinya, izin kerja terkait dengan hak dan kewajiban antara anak dengan pengusaha, misalnya mengenai ketentuan jam kerja, pembayaran upah dengan ketentuan yang berlaku, upah lembar, hal ini orang tua harus mengetahuinya apakah pekerjaan yang dilakukan oleh anak tersebut tidak mengganggu perkembangan anak, baik fisik, mental, maupun sosialnya, mengingat anak masih memerlukan waktu dan kondisi yang mungkin anak dapat tumbuh kembang secara wajar.

Oleh karena itu, secara normatif dapat dikatakan bahwa tidak ada izin tertulis dari orang tua, jelas menyalahi ketentuan Pasal 69 ayat (2) huruf a UndangUndang Nomor 13 Tahun 2003 
tentang Ketenagakerjaan dan ini merupakan pelanggaran persyaratan kerja dalam mempekerjakan anak yang dapat dikenakan sanksi pidana sebagaimana diatur dalam Pasal 185 UndangUndang Nomor 13 Tahun 2003 tentang Ketenagakerjaan yang menentukan dikenakan sanksi pidana penjara paling singkat 1 (satu) tahun dan paling lama 4 (empat) tahun dan/atau denda paling sedikit Rp. 100.000.000,00 (seratus juta rupiah) dan paling banyak Rp. 400.000.000,00 (empat ratus juta rupiah).

Berkaitan dengan izin orang tertulis, seharusnya pengusaha memaksa anak untuk melengkapi persyaratan tersebut, sebab apabila terjadi risiko yang tidak diinginkan, misalnya kecelakaan kerja atau hal-hal lain yang dapat merugikan anak yang bekerja pengusaha tidak dipersalahkan atasdasarpelanggaranpersyaratan kerja sebagaimana diatur dalam Pasal 69 ayat (2) huruf a UndangUndang Nomor 13 Tahun 2003 tentang Ketenagakerjaan, sebab persyaratan tersebut merupakan keharusan yang ditegakkan dengan sanksi, baik sanksi pidana maupun denda sebagai upaya paksa ditaatinya ketentuan persyaratan tersebut.

b) Tidak didasarkan pada perjanjian kerja

Berdasarkan penelitian yang dilakukan terhadap beberapa industri rumah tangga atau industri kecil, pada dasarnya menyatakan bahwa rata-rata tidak ada perjanjian kerja secara tertulis yang dibuat antara pengusaha orang tua/wali anak yang bekerja. Pengecualian dalam hal adanya izin dari orang tua, perjanjian kerja, hubungan kerja yang jelas dan menerima upah sesuai dengan ketentuan yang berlaku, jika anak bekerja pada usaha keluarga.

c) Kondisi jam kerja yang panjang Pasal 69 ayat (2) huruf c Undang-Undang Nomor 13 Tahun 2003 tentang Ketenagakerjaan mengatur, bahwa pekerja anak maksimal bekerja selama 3 jam. Ketentuan tersebut sering dilanggar, meskipun sudah ada batasan ketentuan jam kerja bagi anak-anak yang bekerja, akan tetapi dalam kenyataannya anakanak bekerja di atas 3 jam.

Kondisi faktual berdasarkan hasil penelitian, rata-rata pengusaha sektor informal tidak menetapkan jadwal jam kerja, kecuali mulai jam kerja, yaitu berkisar antara jam 07.00 atau jam 08.00, namun selesainya tidak menentu bahkan ada yang tergantung pekerjaan, seperti pedagang asongan minuman dan makanan kecil, kecenderungan pekerja anak ini apabila menjual barang dagangannya habis atau paling tidak sisa barangnya tidak banyak, karena penghasilannya juga akan sedikit dan tidak jarang dimarahi oleh pemilik dagangan. 
d) Kondisi tempat kerja kurang kondusif dan terganggunya kesehatan tenaga kerja anak Tenaga Kerja anak sering dihadapkan pada risiko-risiko pekerjaanyang dilakukan terutama yang bekerja di sektor industri, seperti risiko gangguan kesehatan akibat ruangan yang pengap, asap industri yang menyesakan nafas, makan dan minum yang tidak terjamin atau kurang gizi juga dihadapkan pada gangguan psikis, seperti caci maki, kata-kata kasar, dan gangguan kehidupan sosialnya, seperti hubungan dengan teman sebaya, frekuensi bertemu dengan tetangga maupun keluarga berkurang atau terbatas, apalagi kalau tempat bekerjanya campur dengan orang dewasa.

Percampuran tempat kerja anak dengan tempat kerja orang dewasa tidak seharusnya dilakukan, karena hal ini bertentangan dengan Pasal 72 Undang-Undang Nomor 13 Tahun 2003 tentang Ketenagakerjaan yang mengatur, bahwa dalam hal anak dipekerjakan bersamasama pekerja/buruh dewasa, maka tempat kerja anak harus dipisahkan dari tempat kerja pekerja/buruh dewasa.

e) Upah yang tidak sesuai dengan ketentuan yang berlaku

Upah harus memenuhi kebutuhan dasar tenaga kerja dan memberikan pendapatan tambahan bagi mereka dan pemotong upah sebagai tindakan penghukuman (pendisiplinan) serta pemotongan upah yang tidak dinyatakan dalam undang-undang nasional tidak boleh dilakukan tanpa izin tenaga kerja yang bersangkutan.

Secara teori ancaman pidananya 4 (empat) tahun untuk pelanggaran terhadap praktik tersebut tergolong berat sebagaimana diatur dalam Pasal 185 UndangUndang Nomor 13 Tahun 2003 tentang Ketenagakerjaan. Hal ini menunjukkan, bahwa pembentuk undang-undang mempunyai perhatian yang cukup terhadap perlindungan hukum untuk tenaga kerja anak, namun di negaranegara berkembang yang tenaga kerjanya melimpah (banyak), mekanisme ancaman pidana untuk mendukung keberlakuan kewajiban atau larangan di bidang ketenagakerjaan kurang atau tidak efektif.

2) Pekerjaan untuk mengembangkan bakat dan minat

Menurut Pasal 71 UndangUndang Nomor 13 Tahun 2003 tentang Ketenagakerjaan, pengusaha yang mempekerjakan anak untuk mengembangkan bakat dan minatnya wajib memenuhi syarat-syarat sebagai berikut: ${ }^{65}$
a) Di bawah pengawasan langsung orang tua atau wali.

65 Pasal 71 ayat (2) Undang-Undang Nomor 13 Tahun 2003 tentang Ketenagakerjaan. 
b) Waktu kerja paling lama 3 (tiga) jam sehari.

c) Kondisi dan lingkungan kerja tidak mengganggu perkembangan fisik, mental, sosial, dan waktu sekolah.

Praktiknya berkaitan dengan waktu kerja memuat kondisi jam kerja yang panjang melebihi batas 3 jam, sehingga waktu yang seperti itu merupakan perbuatan dalam kategori pelanggaran yang dapat diancam dengan sanksi pidana berupa sanksi pidana kurungan paling singkat 1 (satu) bulan dan paling lama 12 (dua belas) bulan dan/atau dengan denda paling sedikit Rp. 10.000.000,00 dan paling banyak Rp. 100.000.000,00.

3) Pekerjaan yang merupakan bagian dari kurikulum pendidikan dan pelatihan

Menurut Pasal 70 UndangUndang Nomor 13 Tahun 2003 tentang Ketenagakerjaan, bahwa anak dapat melakukan pekerjaan di tempat kerja yang merupakan bagian dari kurikulum pendidikan dan pelatihan yang disahkan oleh pejabat yang berwenang dengan syarat-syarat sebagai berikut:

a) Usia anak minimal 14 (empat belas) tahun.

b) Diberi petunjuk yang jelas tentang cara pelaksanaan pekerjaan serta bimbingan dan pengawasan dalam melaksanakan pekerjaan. c) Diberi perlindungan keselamatan dan kesehatan kerja.

Bagaimana dengan status anak yang berusia 15 (lima belas) tahun sampai kurang dari 18 (delapan belas) tahun, apakah termasuk sebagai orang dewasa yang mampu melakukan perikatan atau hubungan kerja? Sungguh merupakan masalah hukum bagi pengusaha yang ingin mempekerjakan anak yang berusia antara 15 (lima belas) tahun dan 18 (delapan belas) tahun, karena dilihat dari usia masih berstatus anak, karena tidak dapat dipekerjakan.

a. Adanya pekerjaan yang dijanjikan Di dalam Pasal 52 Undang-Undang Nomor 13 Tahun 2003 tentang Ketenagakerjaan diatur mengenai syaratsyarat sahnya perjanjian kerja yang dapat dibandingkan dengan Pasal 1320 KUH Perdata melalui tabel sebagai berikut: ${ }^{66}$

$66 \quad$ Hardijan Rusli, Op. Cit., hlm. 56. 


\section{Tabel 2.}

Perbedaan antara Pasal 52 Undang-Undang Nomor 13 Tahun 2003 dengan Pasal 1320 KUH Perdata

\begin{tabular}{|l|l|}
\hline $\begin{array}{l}\text { Pasal 52 Undang-Undang Nomor 13 } \\
\text { Tahun 2003 }\end{array}$ & \multicolumn{1}{c|}{ Pasal 1320 KUH Perdata } \\
\hline Kesepakatan kedua belah pihak & $\begin{array}{l}\text { Sepakat mereka yang mengikatkan } \\
\text { dirinya }\end{array}$ \\
\hline $\begin{array}{l}\text { Kemampuan dan kecakapan } \\
\text { melakukan perbuatan hukum }\end{array}$ & $\begin{array}{l}\text { Kecakapan untuk membuat seuatu } \\
\text { perikatan }\end{array}$ \\
\hline Adanya pekerjaan yang dijanjikan & Suatu hal tertentu \\
\hline $\begin{array}{l}\text { Pekerjaan yang dijanjikan tidak } \\
\text { bertentangan dengan ketertiban } \\
\text { umum, kesusilaan, dan peraturan } \\
\text { perundang-undangan yang berlaku }\end{array}$ & Suatu sebab yang halal \\
\hline
\end{tabular}

Pasal 52 Undang-Undang Nomor 13 Tahun 2003 tentang Ketenagakerjaan mengatur persyaratan sahnya suatu perjanjian kerja, sedangkan Pasal 1320 KUH Perdata mengatur tentang syarat perjanjian pada umumnya. Pasal 52 Undang-Undang Nomor 13 Tahun 2003 tentang Ketenagakerjaan dimaksudkan sebagai hukum khusus, sedangkan Pasal 1320 KUH Perdata adalah suatu hukum yang umum, karena berlaku untuk perjanjian secara umum.

Berikut ini beberapa hal yang berkaitan dengan Pasal 52 Undang-Undang Nomor 13 Tahun 2003 tentang Ketenagakerjaan, yaitu:

1) Hal yang harus ada dalam perjanjian kerja

Suatu perjanjian hal tertentu dalam Pasal 1320 KUH Perdata menunjuk pada perjanjian yang dibuat untuk itu merupakan perjanjian tertentu dan pokoknya atau objeknya harus tertentu atau jelas. Suatu perjanjian yang dibuat itu harus jelas merupakan perjanjian apa? Apakah perjanjian itu adalah perjanjian kerja, jual beli, sewa menyewa atau hanya perjanjian pinjam meminjam saja? Pokok atau objek perjanjian itu juga harus jelas yang mana? Pasal 1320 KUH Perdata menetapkan, bahwa hanya barang-barang yang dapat diperdagangkan saja yang dapat menjadi objek suatu perjanjian. Pada saat membuat perjanjian, boleh jumlah barang belum pasti, tetapi di kemudian hari harus dapat ditentukan atau dihitung. Barang-barang yang baru akan ada di kemudian hari dapat menjadi pokok suatu perjanjian, misalnya panen di kemudian hari, tetapi untuk suatu warisan yang belum terbuka, tidak boleh menjadi pokok perjanjian.

Sementara itu, dalam suatu perjanjian kerja menurut Pasal 52 ayat (1) Undang-Undang Nomor 13 Tahun 2003 tentang Ketenagakerjaan mengenai adanya 
pekerjaan yang diperjanjikan memang seakan-akan sudah dimengerti, bahwa perjanjian yang dimaksud adalah perjanjian kerja, tetapi bagaimana dengan pokok perjanjiannya, apakah hanya ada pekerjaan saja? Pengertian perjanjian kerja menurut Pasal 1 angka 14 Undang-Undang Nomor 13 Tahun 2003 adalah suatu perjanjian antara pekerja/buruh dengan pengusaha/pemberi kerja yang memuat syarat-syarat kerja, hak dan kewajiban para pihak. Definisi perjanjian kerja ini tidak jelas apa prestasi atau kewajiban masing-masing pihak, sehingga bila pihak pekerja menyerahkan atau menyelesaikan pekerjaan, lalu kontraprestasi dari pihak pengusaha adalah bukan menyerahkan uang, melainkan menyerahkan suatu barang atau pekerjaan yang lain pula.

Mengerjakan pekerjaan hanya merupakan kewajiban dari pekerja/buruh dan ini merupakan hak bagi pengusaha untuk menerima pekerjaan, sedangkan bagi pekerja/buruh adalah menerima pembayaran uang dan ini merupakan kewajiban bagi pengusaha untuk melakukan pembayaran uang.

Hal tertentu dalam perjanjian kerja mencakup perjanjiannya harus tertentu sebagai perjanjian apa dan pokok perjanjian atau objeknya harus tertentu pula. Hal yang tertentu dalam perjanjian kerja bukan hanya perlu ada pekerjaan saja, tetapi ada yang lainnya, yaitu pembayaran, karena itu sungguh kurang tepat kalau menetapkan, bahwa syarat sahnya perjanjian kerja hanya memerlukan pekerjaan saja.

2) Suatu perjanjian kerja tidak perlu ada sebab

Pasal 52 Undang-Undang Nomor 13 Tahun 2003 jelas menghilangkan syarat sebab untuk sahnya suatu perjanjian kerja. Apakah suatu perjanjian kerja tidak membutuhkan sebab seperti yang dirumuskan dalam Pasal 1320 KUH Perdata? Berdasarkan penjelasan Pasal 52 UndangUndang Nomor 13 Tahun 2003 tentang Ketenagakerjaan, tidak tepat karena tidak menentukan suatu perjanjian kerja harus ada sebab yang halal, tetapi tidak bertentangan dengan ketertiban umum, kesusilaan, dan peraturan perundang-undangan.

Menyerahkan (mengerjakan) pekerjaan dari pekerja memang merupakan sebab bagi pihak pengusaha, tetapi bagaimana dengan sebab bagi pekerja/ buruh? Sebab bagi pihak pekerja/ buruh untuk menyerahkan (menyelesaikan) pekerjaan adalah penyerahan uang (upah) dari pengusaha.

b. Pekerjaan yang dijanjikan tidak bertentangan dengan ketertiban umum, kesusilaan, dan peraturan perundang-undangan yang berlaku Pasal 52 ayat (1) Undang-Undang Nomor 13 Tahun 2003 mengatur 
persyaratan sahnya suatu perjanjian kerja yang secara subjektif konsekuensi perjanjiannya dapat dibatalkan, apabila perjanjian kerjayang dibuatoleh parapihak bertentangan dengan kesepakatan dan kemampuan atau kecakapan, sedangkan apabila pekerjaan yang diperjanjikan bertentangan dengan ketertiban umum, kesusilaan, dan peraturan perundangundangan yang berlaku akibat hukumnya batal demi hukum. Perjanjian yang dapat dibatalkan adalah suatu perjanjian yang dari semula sah atau mengikat, tetapi perjanjian tersebut dapat dimintakan pembatalannya, sedangkan perjanjian yang batal demi hukum adalah suatu perjanjian yang dari semula tidak sah, artinya tidak pernah terjadi perikatan sejak awal.

Pengertian tentang bertentangan dengan ketentuan kesepakatan dan kemampuan atau kecakapan tidak jelas dalam Undang-Undang Nomor 13 Tahun 2003 maupun dalam penjelasannya. Kalau dilihat dari Pasal 52 ayat (1) UndangUndang Nomor 13 Tahun 2003 yang mensyaratkan suatu perjanjian untuk menjadi sah harus ada kesepakatan dan kemampuan atau kecakapan, maka kata bertentangan dengan ketentuan Pasal 52 ayat (1) itu dapat diartikan sebagai tidak ada kesepakatan dan kemampuan/ kecakapan. Perjanjian yang bertentangan atau tidak ada kesepakatan atau kemampuan/kecakapan adalah perjanjian yang dapat dibatalkan. Perjanjian yang dapat dibatalkan adalah perjanjian yang sah, tetapi perjanjian itu dapat dibatalkan. Artinya sepanjang perjanjian itu tidak dibatalkan, maka perjanjian tersebut adalah tetap perjanjian yang sah.

\section{PENUTUP}

Pasal 1 angka 15 jo. Pasal 50 - Pasal 66 Undang-Undang Nomor 13 Tahun 2003 subjek hukum dari hubungan kerja adalah pengusaha dengan pekerja/ buruh, sehingga batasan subjek hukum berdasarkan ketentuan di atas sangat sempit. Batasan subjek hukum akan berbeda apabila didasarkan pada ketentuan Pasal 1 angka 14 UndangUndang Nomor 13 Tahun 2003, yaitu perjanjian kerja adalah perjanjian antara pekerja/buruh dengan pengusaha atau pemberi kerja yang memuat syaratsyarat kerja, hak, dan kewajiban para pihak. Apabila dilakukan perbandingan antara ketentuan Pasal 1 angka 14 dengan ketentuan Pasal 1 angka 15 jo. Pasal 50 Pasal 66 Undang-Undang Nomor 13 Tahun 2003, maka terdapat perbedaan akibat hukumnya. Unsur-unsur dari ketentuan Pasal 1 angka 14 Undang-Undang Nomor 13 Tahun 2003 adalah subjek hukum perjanjian kerja terdiri dari pekerja/buruh dengan pengusaha atau pemberi kerja, sedangkan yang menjadi objek perjanjian kerjanya adalah syarat-syarat kerja, hak, dan kewajiban para pihak. Unsur-unsur tersebut berbeda dengan ketentuan Pasal 1 angka 15 jo. Pasal 50-Pasal 66 Undang-Undang Nomor 13 Tahun 2003 dengan subjek hukum perjanjian kerjanya adalah pengusaha dengan pekerja/buruh, sedangkan yang menjadi objek perjanjian kerjanya adalah pekerjaan, upah, dan perintah. 


\section{DAFTAR PUSTAKA}

Abdul Rachmad Budiono, Hukum Perburuhan di Indonesia, Raja Grafindo Persada, Jakarta, 1999.

,Hukum Perburuhan, Indeks, Jakarta, 2009.

Achmad Ali, Keterpurukan Hukum di Indonesia (Penyebab dan Solusinya), Ghalia Indonesia, Jakarta, 2005.

Adrian Sutedi, Hukum Perburuhan, Sinar Grafika, Jakarta, 2009.

Amidhan, "Tinjauan Tingginya Angka Pengangguran dari Perspektif Hak Asasi Manusia", Semiloka Memetakan Akar Masalah dan Solusi Tingginya Angka Pengangguran di Indonesia, Purwakarta, 18-19 Juli 2005.

Asri Wijayanti, Menggugat Konsep Hubungan Kerja, Lubuk Agung, Bandung, 2011.

Elfrianto, "Hak atas Pendidikan dan Perlindungan Hukum Pekerja Anak", Jurnal Madani Vol. 8 No. 2, FKIP Universitas Muhammadiyah, Sumut, 2007.

Hardijan Rusli, Hukum Ketenagakerjaan Berdasarkan UU No. 13 Tahun 2003 tenang Ketenagakerjaan dan Peraturan Terkait Lainnya, Ghalia Indonesia, Bogor, 2011.
Iman Soepomo, Hukum Perburuhan Bidang Hubungan Kerja, Djambatan, Jakarta, 1983.

, Pengantar Hukum Perburuhan, Djambatan, Jakarta, 1999.

Juanda Pangaribuan, Kedudukan Dosen dalam Hukum Ketenagakerjaan, BIS, Jakarta, 2011.

Koko Kosidin, "Aspek-aspek Hukum dalam Pemutusan Hubungan Kerja di Lingkungan Perusahaan Perseroan (Persero)", Disertasi, Program Pascasarjana Universitas Padjadjaran, Bandung, 1996.

Mohd. Syaufii Syamsudin, Norma Perlindungan dalam Hubungan Industrial, Sarana Bhakti Persada, Jakarta, 2004.

Peter Mahmud Marzuki, Penelitian Hukum, Prenada Media Group, Jakarta, 2005.

Soedarjadi, Hukum Ketenagakerjaan di Indonesia, Pustaka Yustisia, Yogyakarta, 2008.

Subekti, Hukum Perjanjian, Intermasa, Jakarta, 1979. ,Aneka Perjanjian, Alumni, Bandung, 1985.

Theo Huijbers, Filsafat Hukum, Kanisius, Yogyakarta, 1995. 
Toto Tohir Suriaatmadja, "Aspek Perlindungan Hukum dalam Hukum Ketenagakerjaan", Makalah Seminar Nasional yang Diselenggarakan Program Doktor Ilmu Hukum Pascasarjana UNISBA, Savoy Homann Bidakara Hotel, Bandung, 23 November 2013.

Ujang Charda S., "Reorientasi Reformasi Model Hukum Ketenagakerjaan dalam Kebijakan Pemerintah", Jurnal Ilmu Hukum Syiar Hukum, Vol. XIV No. 1, Fakultas Hukum UNISBA, Bandung, Maret 2012.

, Mengenal Hukum Ketenagakerjaan Indonesia (Sejarah, Teori \& Praktiknya di Indonesia, FH UNSUB, Subang, 2014. , “Tanggung Jawab Negara Indonesia dalam Perlindungan Hukum Terhadap Tenaga Kerja Anak", Jurnal Wawasan Hukum, Vol. 30 No. 1, STHB, Bandung, Maret 2014.

, "Perlindungan Hukum Terhadap Tenaga Kerja Anakyang Bekerja di Luar Hubungan Kerja pada Bentuk-bentuk Pekerjaan Terburuk Dihubungkan dengan Prinsip Tanggung Jawab Negara Hukum", Disertasi, Program Pascasarjana UNISBA, Bandung, 2015. , Perlindungan Hukum Terhadap Anak dari Bentuk-bentuk Pekerjaan Terburuk, Fakultas Hukum Universitas Subang, Subang, 2015.
Hukum Terhadap Tenaga Kerja", Jurnal Wawasan Hukum, Vol. 32 No. 1, STHB, Bandung, Maret 2015.

$\begin{array}{lrr}\text { Transformasi Politik } & \text { Hukum } \\ \text { Ketenagakerjaan Indonesia } & \text { (Sebuah } \\ \text { Orientasi } & \text { Reformasi } & \text { Kebijakan } \\ \text { Pemerintah } & \text { Indonesia } & \text { dalam } \\ \text { Pembangunan } & \text { Ketenagakerjaan), } \\ \text { Fakultas Hukum Universitas Subang, } & \text { Subang, 2016. }\end{array}$

